\title{
Contributions of community and individual small-scale logging to sustainable timber management in Cameroon
}

\author{
G. LESCUYER ${ }^{1,2}$, P.O. CERUTTI ${ }^{3}$ and R. TSANGA ${ }^{2}$ \\ ${ }^{1}$ Centre de coopération Internationale en Recherche Agronomique pour le Développement, BP 2572, Yaoundé, Cameroon \\ ${ }^{2}$ Center for International Forestry Research, Hub for Central Africa, P.O. box 2008, Yaoundé, Cameroon \\ ${ }^{3}$ Center for International Forestry Research, Hub for Eastern Africa, Nairobi, Kenya
}

Email: lescuyer@cirad.fr

\begin{abstract}
SUMMARY
In Cameroon, sustainable timber management relies on the model of large logging concession. However, over the past fifteen years, small-scale logging has become a common activity, with two different forms. First, the creation of community forests in the late 1990s allowed village associations to legally harvest, process and trade timber, almost always with the support of external actors such as NGOs or private operators. Second, individual chainsaw milling, almost always informal, has grown considerably. The article compares the economic, social and environmental impacts of these two options of small-scale logging. Although much focus has been put on community forestry over the latest two decades, it remains a marginal activity with a turnover of less than $€ 2$ million per year and a small impact on rural economies. Conversely, informal chainsaw milling represents an annual turnover of $€ 93$ million, with a flow of revenues around $€ 30$ million for the benefit of rural population. From an environmental perspective, none of the two options seems to substantially conserve or degrade forest resources, but more research is needed on the issue.

The chainsaw milling sector remains largely ignored by - national and international - public policies in the attempts to achieve sustainable timber management in Cameroon. Some perspectives are proposed to legalise the small-scale logging sector without reducing its current socio-economic impact on rural and urban livelihoods.
\end{abstract}

Keywords: chainsaw milling, sustainable forest management, community forest

\section{Contributions des exploitations artisanales communautaire et individuelle à la gestion durable du bois d'œuvre au Cameroun}

\section{G. LESCUYER, P.O. CERUTTI et R. TSANGA}

Au Cameroun, la gestion durable du bois d'œuvre repose sur le modèle de la concession forestière de grande taille. Pourtant, sur les quinze dernières années, l'exploitation artisanale du bois est devenue une activité courante, en prenant deux formes. Tout d'abord, la création des forêts communautaires à la fin des années 1990 a permis à des associations villageoises d'abattre, de transformer et de vendre légalement du bois, presque toujours avec le support d'acteurs extérieurs tels que des ONG ou de opérateurs privés. D'un autre côté, l'activité individuelle de sciage à la tronçonneuse, presque toujours informelle, a considérablement grandi. L'article compare les impacts économiques, sociaux et environnementaux de ces deux options d'exploitation artisanale du bois. Quoique beaucoup d'attention ait été portée sur la foresterie communautaire depuis vingt ans, elle reste une activité marginale avec un chiffre d'affaires inférieur à 2 millions $€$ par an et un faible impact sur les économies rurales. A l'inverse, l'exploitation individuelle représente un chiffre d'affaires annuel de 93 millions $€$ et un flux de revenus autour de 30 millions $€$ au bénéfice des populations rurales. Dans une perspective environnementale, aucune de ces deux options ne semble conserver ou dégrader substantiellement les ressources forestières, mais davantage d'études sont nécessaires sur cet aspect.

Le secteur de l'exploitation artisanale du bois reste largement ignoré par les politiques publiques - nationale et internationale - pour permettre une gestion durable du bois d'œuvre au Cameroun. Plusieurs perspectives sont proposées pour légaliser l'exploitation à petite échelle sans réduire son impact socio-économique actuel sur les conditions de vie rurales et urbaines.

\section{Las contribuciones de las comunidades y de la tala individual de pequeña escala a la gestión sostenible de la madera en Camerún}

\section{G. LESCUYER, P.O. CERUTTI y R. TSANGA}

En Camerún, la gestión sostenible de la madera se basa en el modelo de la gran concesión maderera. Sin embargo, durante los últimos quince años, la explotación forestal a pequeña escala se ha convertido en una actividad más común, en torno a dos formas distintas. En primer lugar, la creación de bosques comunitarios a finales de 1990 permitió que las asociaciones comunitarias cosecharan, transformaran y comerciaran 
madera legalmente, casi siempre con el apoyo de agentes externos como ONG u operadores privados. En segundo lugar, el aserrado con motosierra individual, casi siempre informales, ha crecido considerablemente. Este artículo compara los impactos económicos, sociales y ambientales de estas dos formas de tala a pequeña escala. Aunque una gran atención se ha centrado en la silvicultura comunitaria durante las últimas dos décadas, ésta sigue siendo una actividad marginal con una facturación inferior a 2 millones $€$ por año y con un pequeño impacto en las economías rurales. Por lo contrario, el aserrado informal con motosierra representa una facturación anual de 93 millones $€$, con un flujo de ingresos de unos 30 millones de $€$ para el beneficio de la población rural. Desde una perspectiva ambiental, ninguna de las dos formas parece conservar o degradar sustancialmente los recursos forestales, pero se necesita más investigación sobre el tema.

El sector del aserrado con motosierra permanece en gran medida ignorado por políticas públicas - nacionales e internacionales - en sus intentos de lograr una gestión sostenible de la madera en Camerún. Se proponen algunas sugerencias para fomentar la legalidad en el sector de la explotación forestal a pequeña escala sin reducir su actual impacto socioeconómico sobre los medios de vida rurales y urbanos.

\section{INTRODUCTION}

The evolution of the paradigm of sustainable development in the 1980s and 1990s, and the debate on forests that was re-launched at the 1992 Earth Summit resulted in significant changes in the views on how tropical forests were to be managed. The principle of Sustainable Forest Management (SFM) was the most immediate translation of these changes (Smouts 2001), and it was based on economic, ecological and social foundations. In the realm of strong sustainability, the natural capital is to a great extent non-substitutable (Dietz and Neumayer 2007), and SFM thus becomes the use of natural forest which indefinitely maintains the forest substantially unimpaired in the environmental services it provides, as well as in its biological quality (Goodland et al. 1991, Poore et al. 1989). A more economical and technical vision is also proposed for SFM, defined as the production of continuous flow of desired forest products and services without undue reduction of its inherent values and future productivity and without undue undesirable effects on the physical and social environment (D'Silva and Appanah 1993, Luckert and Williamson 2005, Toman and Ashton 1996). Lastly, for social scientists, SFM aims at integrating social forestry into forest management, as a way to improve the livelihoods options of the rural people living in or near the areas where logging operations take place (Cernea 1986, Wiersum 1999).

The various dimensions and the inherent difficulties in agreeing on a single definition of SFM are also evident in the guidelines for the sustainable management of natural forests that were debated and published in the 1990s, like the ITTO's (Karsenty et al. 2004). There, SFM is broadly defined as a system of forest management that aims for sustained yields of multiple products from the forest in order to achieve environmental, economic and social objectives (Panayotou and Ashton 1992, Pearce et al. 1999). Hence, much was left to each institution or country not only to decide where SFM should be applied, but also to translate "sustained yields" into technical regulations that logging companies, private individuals or communities could apply on the ground.

By and large, the revision of the forestry laws in Central Africa that followed the Earth Summit placed SFM at the heart of the new forest policies (Assembe Mvondo 2009). Those legal frameworks mandated the sustainable management of large-scale logging concessions by export-oriented industrial companies (Karsenty et al. 2004, Leroy et al. 2013).
However, over the years, it became evident that the notion of SFM as implemented on the ground in Central Africa was a reduced version of the original one, largely focussing on timber extraction, with the exception of the FSC-certified companies that make substantial investment in wildlife management and social development. But for the majority of the concessions, it is thus more appropriate to talk about sustainable timber management (STM), in which the focus is on a sustained yield of timber over long time periods through investment in rational harvesting and regeneration (Pearce et al. 1999).

One of the first countries to adopt a new forest law, in 1994, was Cameroon. This type of exploitation has provided valuable economic benefits (Cerutti et al., this issue) and, concurrently with a weak development of road infrastructure, it has also resulted in low levels of deforestation (Bruggeman et al. 2015, Desclée et al. 2014). Its impacts on biodiversity are, however, still a matter of discussion among academia and practitioners (Abernethy et al. 2013, Karsenty and GourletFleury 2006, Nasi et al. 2012), as well as its contribution to poverty alleviation and to the improvement of socio-economic conditions (Counsell et al. 2007, Eisen et al. 2014, Leroy et al. 2013, Lescuyer et al. 2012, Samyn et al. 2011).

The often criticized social performance of most logging concessions can be partly explained by the philosophy that guided the development of the forestry code in 1994. While the concession model was introduced to maximize financial income to the state and to maintain the forest cover, the stated policy objective of the Community Forest (CF) model was to offer communities the opportunity to manage, and indeed use, forest resources for their own benefit and, to some extent, according to their own rules (Ekoko 2000, Topa et al. 2009). The sustainability of this latter model is theoretically guaranteed by the development and implementation of a Simple Management Plan (SMP), prepared by the community and approved by the administration. Yet, environmental considerations are not the main purpose of the creation of $\mathrm{CFs}$, as they are primarily assigned a social objective (Assembe Mvondo et al. 2011, Cuny et al. 2004, Etoungou 2003, Oyono 2005) and they have been confined by the State to the Non-Permanent Forest Estate (NPFE). To that aim, timber exploitation in CFs must be conducted with artisanal means of production and be carried out collectively over a maximum area of 5000 hectares.

This new form of participatory forest management has enjoyed international support since the late 1990s and in 
2010: out of 291 validated SMPs, 182 had been completed with the signing of a letter of agreement with the public authorities, covering a surface of 677,233 hectares. However, only 140 of these were actually operational, having received a Certificate of Harvesting License (CHL). Hence, twenty years after their creation, it is only about $1 \%$ of the national area of Cameroon or $5 \%$ of the production forest area which is operated under CF status.

Compared to the ambitions of the original policy (Cuny et al. 2004), the current results can be seen as a failure. Concurrently, there has been a boom of informal, small-scale and largely individual logging operations over the same period (Cerutti and Lescuyer 2011). The growth of the individual chainsaw milling sector dates back to the second half of the 1990s, when the gradual improvement in economic conditions, particularly in the cities, coupled with the absence of alternative sources of income in rural areas, pushed many Cameroonians to become artisanal sawyers. Their production replaced that of industrial companies to supply urban markets (Plouvier et al. 2002) and supplemented exports to neighbouring countries. In 1999, the Ministry of Forests took the decision to suspend the use and provision of all "small scale" logging titles on the pretext that they had become a major source of corruption and illegality. The suspension remained in force until 2006, but chainsaw logging continued unabated (Cerutti and Tacconi 2008). In fact, instead of reducing illegal logging, the suspension forced an entire sector to operate informally, without access to legal logging titles. Since 2006, when the suspension was lifted, a very limited number of permit applications was delivered by the Ministry, not only because the conditions for access to permits were centralized and expensive, but also because the entire sector is now organized on the basis of informal practices (Cerutti et al. 2013).

Thus, besides the industrial forestry sector largely operating in concessions and mandated by law to maintain the biological diversity of the country, there are today two smallscale, artisanal models of timber harvesting and processing. The two models have several points in common: they mainly rely on chainsaws - or at best chainsaws and mobile sawmills —for felling and processing timber, rural communities are very much engaged in some or all phases of the production process (e.g. access to the resource, harvesting, processing, transport, etc.), and forest operations for both are largely located in the NPFE, which by law does not have a "sustainable" mandate. In the two cases, since the tree is generally processed at the stump, there is no skidding and so less damage to soil and surrounding vegetation compared to industrial logging.

But they also differ on two main issues: community forestry is promoted (at least in theory) as a collective effort and it has a formal legal framework within which it can operate, while chainsaw milling is largely a private, business-oriented, individual profession that operates outside the legal framework and it thus relies on informal practices and contribute almost exclusively to the informal economy. Between these two models, community forestry is generally regarded as the most promising approach in terms of social and environmental impacts, and as such, at least in Cameroon, it has received the support of international donors over the last two decades (Cuny 2011, Eisen et al. 2014).

Given the recent research results suggesting that artisanal logging is on the rise across Central Africa (Bayol et al. 2014), and the availability of new data (e.g. see Cerutti and Lescuyer 2011, Lescuyer et al. 2011, Lescuyer et al. 2013, Lescuyer et al. 2014), we believe it is about time to compare the performance of these two models (CF and artisanal logging). This paper thus assesses their respective performance by using the three pillars of SFM. This is done not only to avoid replicating past mistakes into future policies promoted across the region, but also to provide policy makers with a framework for assessing their future forest-related strategies.

After presenting the methods of analysis and the data used, the economic impacts of community forestry and individual chainsaw milling are estimated at the national level. Social sustainability is then analysed by studying the distribution of income and the application of traditional knowledge and rules. Finally, their ecological sustainability is assessed on the basis of their ability to maintain timber resources and forest cover. The last part of the article summarizes the different impacts and discusses the relationships between legalization and sustainability of small-scale timber exploitation.

\section{METHODS}

The article adopts a SFM perspective and analyzes the financial, social and environmental performances of the two small-scale logging options in Cameroon.

Four criteria are selected to assess the economic performance: turn-over, profit, added value and employment. Costbenefit analysis is used to evaluate the financial benefits. By definition, the financial benefits relate to the revenue streams accruing to the different actors (Brent 2006). Inflows consist of timber sales. They are gross financial benefits, or turnover. Outflows are the actual costs incurred by the actors to obtain financial benefits. Total financial cost aggregates investment, operating and transaction costs. The difference between the gross financial benefit and the financial cost is the net benefit, i.e. the profit that the actors draw from the activity.

In contrast with a standard cost-benefit analysis, this analysis covers only one year, without planning the evolution of these sectors over medium or long-term. The objective is to evaluate their financial importance at the nation scale for one year. To do this, the added value of this sector was calculated by conventionally aggregating net financial benefit, payroll, depreciation of equipment and taxation.

The level of revenues accruing to rural populations, the recognition of their customary rights and the increase in human and social capitals at the community scale - through the development of local organisations and the capacity to appeal to external supports - are considered the variables that describe the social impacts of small-scale logging.

Finally, the environmental outcomes of these small-scale logging options are assessed by the location of timber 
harvesting - inside or outside the NPFE - the direct and indirect potential contributions to forest degradation and the existence of intentional actions to reforest or regenerate timber resources.

These criteria are not enough to provide an exhaustive comparison between community forestry and individual logging, but they have been selected on the basis of a broad review of scientific publications and technical reports. Without being complete, these criteria reveal the main consequences of these two modes of artisanal logging, in a perspective of STM. Still, much information needed to estimate benefits scale is missing or partially available. Several hypotheses have therefore been made for many variables. These assumptions are explicit in the article, firstly, to clarify the understanding of estimations and, secondly, to identify current knowledge gaps on the functioning of these sector. Generally, information from scientific literature was favoured to data from specialized reports. When data were different for the same variable, a low average was used in order to limit the risk of overstatement.

\section{RESULTS}

\section{Financial benefits of individual chainsaw milling}

The annual production of informal sawnwood in Cameroon amounts to $715000 \mathrm{~m}^{3}$, divided between production for domestic consumption and exports (Table 1, adapted from Cerutti and Lescuyer 2011).

Selling prices vary according to quality, type and origin of the product, as well as to the tree species. The average price of a cubic meter of sawnwood is around $€ 130$ on Cameroonian urban markets, including all species and all products (Cerutti and Lescuyer 2011). This value is also used to estimate the selling price on the Chadian and Nigerian markets. Under this assumption, the total turnover of individual chainsaw milling is around $€ 93$ million per year. It generates around 44000 full- and part-time jobs, with $90 \%$ in rural areas (Cerutti and Lescuyer 2011).

Wages contribute the highest percentage to the sale price of informal sawnwood on the Cameroonian market, followed by transportation costs and profit to traders (Table 2, adapted from Cerutti and Lescuyer 2011).

By multiplying the average profit per cubic meter $(€ 22)$ by the total volume $\left(715,000 \mathrm{~m}^{3}\right)$, the annual net benefit of the individual chainsaw milling sector is estimated around $€ 15.7$ million. Its added value amounts to $€ 63$ million per year.

TABLE 1 Annual production and destination of informal chainsawn wood

\begin{tabular}{lllr}
\hline \multirow{2}{*}{$\begin{array}{l}\text { Domestic } \\
\text { consumption }\end{array}$} & \multicolumn{2}{l}{ Informal chainsawn wood } & $662000 \mathrm{~m}^{3}$ \\
\cline { 2 - 4 } & Sawmill scrap & & $198000 \mathrm{~m}^{3}$ \\
\hline \multirow{2}{*}{ Exports } & $\begin{array}{l}\text { Informal } \\
\text { chainsawn wood }\end{array}$ & Chad & $41000 \mathrm{~m}^{3}$ \\
\cline { 2 - 4 } & Sawmill scrap & Chad & $27000 \mathrm{~m}^{3}$ \\
\hline
\end{tabular}

TABLE 2 Components of sales price of sawn wood in domestic markets $\left(€ / m^{3}\right)$

\begin{tabular}{lcc}
\hline Components of final sales price & $\begin{array}{c}\text { Estimation } \\
\left(\boldsymbol{(} / \mathbf{m}^{\mathbf{3}}\right)\end{array}$ & $\mathbf{\%}$ \\
\hline Wages (rural and urban areas) & 43.6 & $34 \%$ \\
\hline Transportation and equipment & 23.1 & $18 \%$ \\
\hline $\begin{array}{l}\text { Consumables and miscellaneous in } \\
\text { rural areas }\end{array}$ & 17.0 & $13 \%$ \\
\hline $\begin{array}{l}\text { Informal payments (rural and } \\
\text { urban areas) }\end{array}$ & 16.3 & $13 \%$ \\
\hline Payment to customary owners & 6.8 & $5 \%$ \\
\hline Official taxes & 0.1 & $0 \%$ \\
\hline Rent for outlet & 0.5 & $0 \%$ \\
\hline Profit (rural and urban areas) & 22.0 & $17 \%$ \\
\hline
\end{tabular}

\section{Financial benefits of community forestry}

The model of CF is not homogeneous (Ezzine et al. 2009): its implementation and its impacts depend on many variables that must be simplified to conduct an economic analysis. Therefore, four sets of assumptions are made to calibrate the scale of community forestry in Cameroon, to assess the start-up costs of a CF, to estimate its operating costs and to calculate the financial benefits of logging.

\section{Hypotheses on the implementation of community forestry in Cameroon}

- Average size of a CF is set at 3,440 ha, as calculated from official statistics, but part of this surface cannot usually be dedicated to timber production due to ecological constraints or to the absence of valuable trees in degraded lands;

- The number of active (i.e. with ongoing operations on the ground) $\mathrm{CFs}$ is set at 150 , i.e. the average number of CHL delivered annually by the forestry administration since 2010;

- $\quad 75 \%$ of the active CFs are operated by private operators contracted by the communities (Cuny 2011) whereas $25 \%$ are operated directly by communities.

\section{Hypotheses on the start-up costs of a CF}

- The inception phase of a CF requires many administrative steps, which cost an estimated $7630 €$ (Cuny 2011, Julve et al. 2007);

- The design and writing of the SMP cost $4 € / \mathrm{m}^{3}$ and the application of the Environmental Impact Assessment (EIA) amounts to $7 € / \mathrm{m}^{3}$ (Cuny 2011, Julve et al. 2007);

- These start-up costs are assumed to be paid off during twenty five years - the duration of the SMP - and to generate revenues that are equally shared between administration and private operators (consultancy firms, NGOs...). 
Hypotheses on the operating costs of a $\mathrm{CF}$

- Preliminary steps of logging generate expenses of $15 € / \mathrm{m}^{3}$ (Cuny 2011, Vermeulen et al. 2006);

- The management committee of the CF costs $12 € / \mathrm{m}^{3}$ (Julve et al. 2007);

- Logging and processing costs for hardwoods are evaluated at $69 € / \mathrm{m}^{3}$ (Julve et al. 2007), and at $47 € / \mathrm{m}^{3}$ for softwoods (Cuny 2011);

- Trade of timber is submitted to various «administrative» charges, with an average expense of $3 € / \mathrm{m}^{3}$ (Castadot 2007, Julve et al. 2007).

Hypotheses on the productivity and income of a CF

- The actual timber production is often very different from the maximum possibility authorised by the Ministry. Nzoyem et al. (2010) noted that the total round-wood equivalent volume for $\mathrm{CFs}$ at the country scale was around $57000 \mathrm{~m}^{3}$ - an average of $900 \mathrm{~m}^{3}$ per $\mathrm{CF}$ - while the average operating rate never exceeded $27 \%$ and was on average around $15 \%$. A $20 \%$ rate of use of the authorized timber volume in the CHL is thus assumed, i.e. an annual volume of about $180 \mathrm{~m}^{3}$ per FC or $60 \mathrm{~m}^{3}$ of sawnwood with a conventional processing rate of $30 \%$ (Cerutti and Lescuyer 2011). Such a production can be done in three months of work for a team of 12 people, i.e. about 3 full time jobs generated by each FC (Nzoyem et al. 2010).

- Half of timber production is done with low-quality hardwood species ("bois blanc") and half with highquality hardwood species ("bois rouge") (Cuny 2011);

- In the case of a CF directly operated by communities, all sawnwood is exported and sold at the Free On Board (FOB) price, that is estimated at $140 € / \mathrm{m}^{3}$ for low-quality hardwoods and $221 € / \mathrm{m}^{3}$ for high-quality hardwoods (Julve et al. 2007);

- CFs operated by communities frequently provide additional income from the sale of secured documents - for instance waybills - to launder illegally produced timber. Ndume Engone (2010) estimated, on a basis of a survey in $4 \mathrm{CFs}$, that trafficking documents increase income by $25 \%$ for communities. The administration takes advantage of this traffic as much as communities (Cuny 2011, REM 2007).

- In the case of CFs operated under contract, the average selling price of sawn wood by communities to private operators is $23 € / \mathrm{m}^{3}$ (Cuny 2011) while the operator makes a supposed benefit of $46 € / \mathrm{m}^{3}$.

Estimates are summarized in Table 3 for the two possible options of timber harvesting in a $\mathrm{CF}$.

If timber exploitation by communities seems a profitable business, in reality the start-up costs are out of their reach: it is indeed necessary to spend more than $€ 13000$ even before signing the CF management agreement with the administration. The requirement to carry out an Environmental Impact Assessment survey - not enforced until recently (Julve et al. 2013 ) - would increase this cost by $€ 10500$. This prohibitive cost to access community forestry in Cameroon explains the frequent dependence of communities vis-à-vis external actors that can financially and technically support the upfront costs of creation and utilization of a CF.

Assuming that all timber production from CFs is exported, annual turnover of community forestry in Cameroon is estimated at $€ 1.63$ million and the net annual benefit around $€ 0.52$ million. The added value of this sector amounts to $€ 1.17$ million per year.

TABLE 3 Costs and benefits of timber production in CFs for a community $\left(€ / \mathrm{m}^{3}\right)$

\begin{tabular}{|c|c|c|}
\hline$€ / \mathbf{m}^{3}$ & $\begin{array}{c}\text { Timber exploitation by the } \\
\text { community }\end{array}$ & $\begin{array}{c}\text { Timber exploitation } \\
\text { subcontracted }\end{array}$ \\
\hline Turn over & 181 & 23 \\
\hline \multicolumn{3}{|l|}{ Start-up costs } \\
\hline Administrative procedures & 5 & 0 \\
\hline Elaboration of SMP & 4 & 0 \\
\hline EIA & 7 & 0 \\
\hline \multicolumn{3}{|l|}{ Operating costs } \\
\hline Preparation of logging & 15 & 0 \\
\hline Logging and processing of softwood species & 47 & 0 \\
\hline Logging and processing of hardwood species & 69 & 0 \\
\hline Management committee & 12 & 0 \\
\hline Other costs & 3 & 0 \\
\hline \multicolumn{3}{|l|}{ Profit } \\
\hline Formal benefit for the community & 19 & 23 \\
\hline Formal and informal benefits for the community & 23 & 23 \\
\hline Benefit for the subcontracted company & 0 & 46 \\
\hline
\end{tabular}


Financial revenues from timber harvesting in CFs should not obscure some economic benefits that this type of management may provide. Four economic benefits are mentioned in the literature: NTFPs extraction (Akoa Akoa 2007, Beauchamp and Ingram 2012), reduction of carbon emissions (Awono et al. 2013, Karsenty et al. 2010, Minang et al. 2007), biodiversity conservation (Beauchamp and Ingram 2012) and maintenance of soil fertility (Beauchamp and Ingram 2012). However, assimilating these economic benefits to CF management requires demonstrating that they would disappear or be severely degraded in the absence of the $\mathrm{CF}$, which is rarely obvious (Ingram et al. 2012, Lescuyer 2013).

\section{Social benefits of individual small-scale logging}

Four categories of actors derive income from informal chainsaw milling: rural communities, urban populations, and representatives of the government and of municipalities (Table 4, adapted from Cerutti and Lescuyer 2011).

Artisanal logging has a direct economic impact in rural economies since half of the operating costs are made in the villages where trees are felled. Rural people are not the only ones to benefit from chainsaw milling. On the one hand, urban populations capture a significant portion of revenues from the sale of artisanal sawnwood. On the other hand, about $13 \%$ of timber price is due to payments unduly made to various forms of public authority. This wide distribution of revenues from individual chainsaw milling strengthens social legitimacy of this informal activity.

Apart from its positive contribution to increase rural revenues, individual chainsaw milling is based on traditional land tenure that frames the sale of trees to sawyers. Artisanal sawing provides an opportunity for customary owners to assert their rights to exploit timber resources (Lescuyer et al. 2013, Oyono 2004).

But the illegal context of individual chainsaw milling restricts its contribution to increasing the human and social capitals of communities. There are still very few associations of artisanal sawyers in Cameroon (Lescuyer et al. 2015). Similarly, at the village level, this activity develops without the need to create a local formal organization. The absence of such committees to supervise individual artisanal logging potentially deprive communities of technical and financial supports from external actors.

\section{Social benefits of community forestry}

Community forestry has been designed to help improve livelihoods of rural people through collective and individual income. Based on the assumptions above, Table 5 summarizes the revenues from logging in 150 active $\mathrm{CFs}$ for the three main actors.

As in the case of chainsaw milling, local people are the primary beneficiary of community forestry, mainly due to wages paid to individual workers. The individual incomes are on average twice as important as the collective benefits (Nzoyem et al. 2010) and constitute about $60 \%$ of the cost of felling and wood processing (Castadot 2007, Julve et al. 2007). The impact of the collective benefits derived from logging in the CFs on local livelihoods is more debatable as they are often captured by local elites (Bigombe Logo 2004, Eisen et al. 2014, Ezzine de Blas et al. 2011, Oyono et al. 2006). Private operators also earn substantial income from community forestry.

In addition to revenues, community forestry enables local people to value at least partially their customary rights. On one hand, the delimitation of a CF is a way to endorse the possession of their customary lands by the community, even if this recognition covers only the area inside the NPFE. On the other hand, SMPs may include provisions for individual customary owners, such as financial compensation for use of resources that belong to them (Oyono et al. 2006, Poissonnet et al. 2006).

TABLE 4 Distribution of annual revenues drawn from individual chainsaw milling

\begin{tabular}{llc}
\hline \multicolumn{1}{c}{ Beneficiaries } & \multicolumn{1}{c}{ Sources of revenues } & Amount (million $€ / \mathbf{y r})$ \\
\hline Rural populations & Wages, sale of trees, profit from chainsaw milling & 30.55 \\
\hline Urban populations & Wages, outlet rental, profit on sale of sawing to end users & 17.63 \\
\hline $\begin{array}{l}\text { Representatives of government or } \\
\text { council authorities }\end{array}$ & $\begin{array}{l}\text { Informal payments at council level, during transport and in urban } \\
\text { markets }\end{array}$ & 10.78 \\
\hline Councils & Final taxes & 0.07 \\
\hline
\end{tabular}

TABLE 5 Distribution of annual revenues drawn from community forestry

\begin{tabular}{ll}
\hline \multicolumn{1}{c}{ Beneficiaries } & \multicolumn{1}{c}{ Sources of revenues } \\
\hline Local populations & Wages, profit from timber sale \\
\hline Administration & Formal and informal costs \\
\hline $\begin{array}{l}\text { Private operators (logging companies, consultants, } 800 \\
\text { NGOs) }\end{array}$ & $\begin{array}{l}\text { Profit from timber sale, design of CF management } \\
\text { documents }\end{array}$ \\
\hline
\end{tabular}


Finally, the creation of a CF local committee often allows to benefit from external supports to strengthen the human and technical capacities in communities, either directly related to community forestry (Ezzine de Blas et al. 2009, Lescuyer 2013) or attracting other donors wishing to rely on the existing local structure to promote rural development (Lescuyer et al. 2015, Meunier et al. 2014, Minang et al. 2007).

\section{Ecological sustainability of individual small-scale logging}

The ecological impacts of chainsaw milling are frequently criticized, but little evidence is usually provided. Yet Cerutti and Lescuyer (2011) show that almost all operating sites were within two kilometres of roads or rivers, almost always in the NPFE and in $65 \%$ of cases in degraded sites, like secondary forests, cocoa plantations, fallows and fields (Figure 1).

In addition, individual sawyers focus on a few commercial timber species - mainly ayous (Triplochyton scleroxylon), movingui (Distemonanthus benthamianus), iroko (Milicia excelsa), sapele (Entandrophragma cylindricum) and bilinga (Nauclea diderrichii) - and look especially for large diameter trees that maximize productivity of sawing. This selective harvesting does not seem to generate a significant degradation of the forest ecosystem. However, it is important to note that negative environmental impacts of informal logging are likely to amplify in the future because of several factors. First, the absence of reforestation by local people. Although local owners rely on their customary rights to sell "their" trees to chainsaw millers, very few of them effectively regenerate these timber resources, as Robiglio et al. (2013) show in the Central region of Cameroon. This may trigger a slow but constant decline in species' availability.

Second, increasing urban demands for timber may aggravate the ecological impacts of chainsaw milling, as sawyers would move further into forest and use more efficient equipment, like mobile saws. Applying a buffer zone of $4 \mathrm{~km}$ around Cameroon's roads (using a map produced by Global Forest Watch and MINFOF 2007) and assuming current logging methods, chainsaw millers could exploit about 8 million ha of land in the NPFE. This zone is shown in yellow in Figure 2 (adapted from Cerutti and Lescuyer 2011), with the

FIGURE 1 Main ecosystems used by chainsaw millers

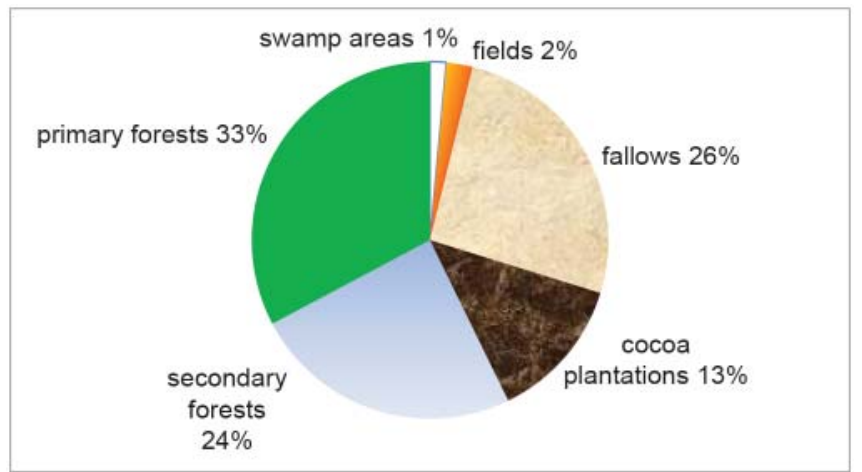

PFE shown in green. Third, the government of Cameroon is no exception among Central African countries to base the current development strategies on large-scale agribusiness and infrastructure projects. If implemented, these could lead to an even more rapid increase of timber demand, as well as clearing of previously forested areas, with low consideration given to ecological impacts, especially in those areas that are not legally mandated to conserve biodiversity.

\section{Ecological sustainability of community forestry}

From a technical point of view, the development of the SMP and its validation by the forestry administration are supposed to ensure the maintenance of forest cover and tree resources in the CF. In addition, any CF is under an obligation to reforestation, to be mentioned in the SMP but very little enforced or controlled (Cuny et al. 2004). However, in most CFs, forest inventories are poorly done and are not used for planning (Cuny 2011, Julve et al. 2007, Vermeulen et al. 2006). The low technical quality of SMPs, the poor enforcement of regulations, and the location of CFs in the NPFE do not promote the maintenance of resources and forest cover (Bruggeman et al. 2015, Cuny et al. 2004, Oyono et al. 2006).

Furthermore, the traffic of waybills from CFs contributes indirectly to forest degradation, by facilitating timber harvesting and transportation that take place outside any legal control. Nobody has estimated the scale of this activity through falsely certified documents issued for CFs, but the substantial and increasing volume of informal exports of ayous to Chad raises serious concerns about the environmental consequences of this business (Lescuyer and Tal 2016).

\section{DISCUSSION}

\section{Artisanal logging options and sustainable timber management}

Table 6 summarizes the current economic, social and ecological performances of CFs and chainsaw milling in Cameroon.

Individual chainsaw milling is an important economic activity for tens of thousands of Cameroonians in both urban and rural areas. In terms of timber volume, employment and income, this sector does at least as well for rural economies as industrial logging (Cerutti et al., this issue) and far surpasses community forestry.

There is still little evidence demonstrating either the supposed low environmental impact of community forestry, or the supposed degradation caused by individual chainsaw milling. But the increasing domestic demands for sawnwood will increase the pressure on timber resources at least in the NPFE over medium term and, so far, no convincing measures are implemented by local population to reforest or regenerate timber resources.

Thus our comparison of these two small-scale logging options indicates that individual chainsaw milling better fulfils the criteria that were set for STM. This finding challenges 
FIGURE 2 Potential exploitation area for individual chainsaw operations

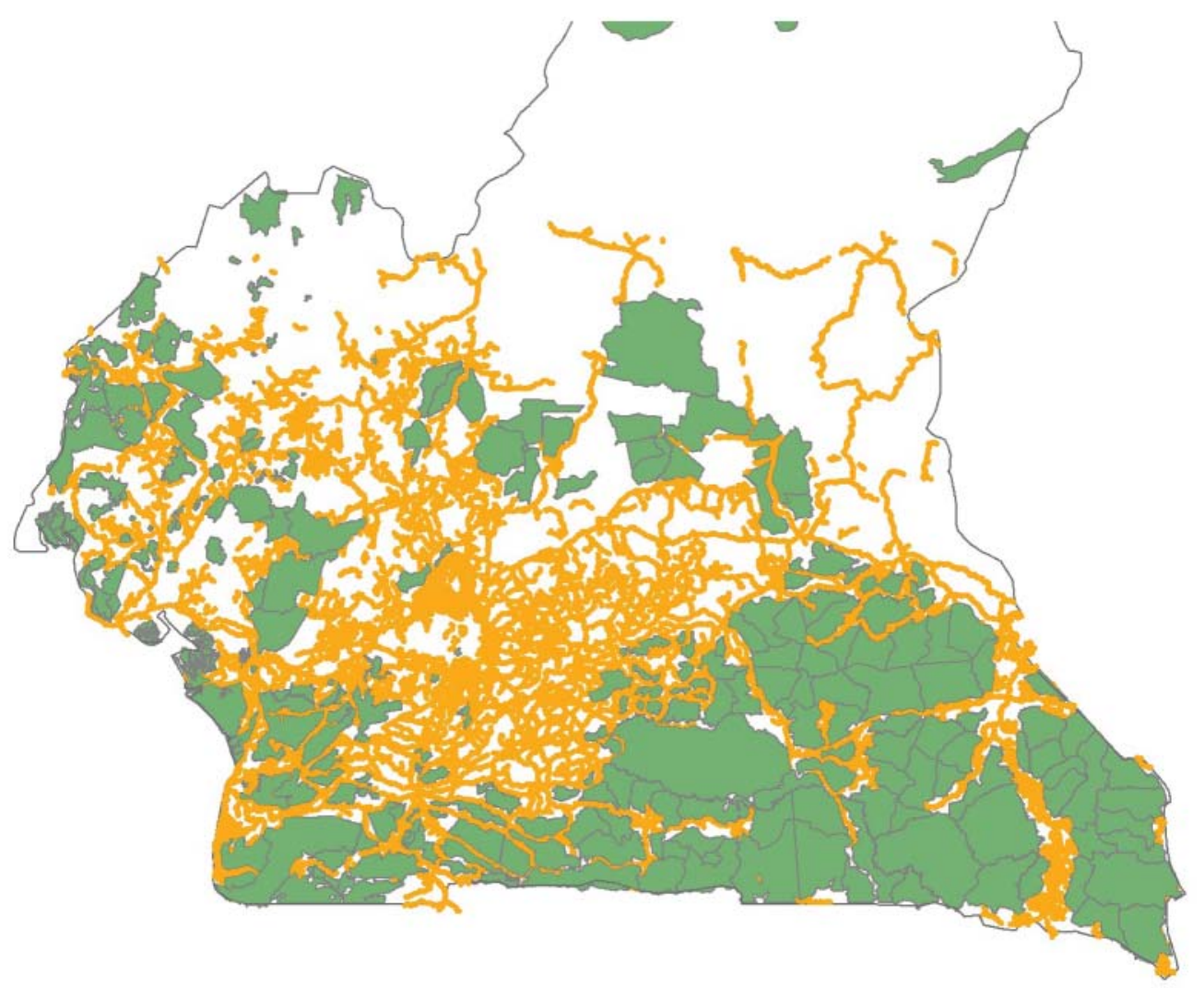

TABLE 6 Synthesized impacts of individual and collective small-scale logging in Cameroon

\begin{tabular}{|c|c|c|}
\hline & Individual chainsaw milling & Community forestry \\
\hline Volume $\left(\mathrm{m}^{3} / \mathrm{yr}\right)$ & 715000 & 9000 \\
\hline Turn-over ( $€ /$ yr) & 93 million & 1.63 million \\
\hline Profit (€/yr) & 15.7 million & 0.52 million \\
\hline Added value $(€ / y r)$ & 63 million & 1.17 million \\
\hline Employment (direct jobs) & 44000 (permanent and temporary) & 450 (permanent) \\
\hline $\begin{array}{l}\text { Social benefits for rural } \\
\text { communities }\end{array}$ & $\begin{array}{ll}\text { - } & 30.5 \text { million } € / y r \\
\text { - } & \text { Valorisation of individual customary rights on } \\
& \text { timber resources }\end{array}$ & $\begin{array}{ll}\text { - } & 0.6 \text { million } € / y r \\
\text { - } & \text { Partial recognition of the community territory } \\
\text { - } & \text { Partial recognition of individual customary } \\
& \text { rights on resources }\end{array}$ \\
\hline Environmental benefits & No clear threat & No clear evidence \\
\hline
\end{tabular}

the relevance of the $\mathrm{CF}$ model as promoted in Cameroon. Lacking a more convincing legal framework that gives CFs the status of areas where biodiversity must be conserved and managed, such outcomes are not surprising. Under the current situation, there still is no guarantee for the populations that the land they register as CF will be respected as such by the government for the entire period over which the "sustainable" rotation (i.e. at least 25 years) should take place. It is a "promise" made by the Ministry of Forests to communities in an environment where the former has a very weak stand within the development strategy of Cameroon. In this situation, it is understandable that communities do not consider CFs as a way to implement anything sustainable, but just as a piece of land that should be freed of all valuable trees before any outsider does it.

\section{Community forests: The expected failure of decentralised forest management?}

Although enshrined in the forestry law and having received various financial supports, formal community forestry is a relative failure in Cameroon. The number of active CFs remains low, most are operated by private operators under contract, and management is often dysfunctional. In general, 
there is a wide gap between the legal requirements for granting and ruling a CF and the community capacities. Julve et al. (2013) show that in a sample of 76 CFs in 2010-2012, no FC fully complies with legal requirements. Of the 37 legality indicators considered, 11 were not applied in more than half of the sampled CFs, and 3 indicators were never implemented.

The persistence of these blockages, already reported ten years ago (Cuny et al. 2004, Etoungou 2003, Vermeulen et al. 2006), tends to support the assumption of a political resistance to promote decentralized forest management in Cameroon (Bigombe Logo 2004, Oyono 2004, Oyono et al. 2006). Without a significant simplification of procedures for creating and managing CFs, it is unlikely that communities will use this option to sustainably manage their forest resources and raise their living standards.

However, one may also wonder how much simplification is needed before the management rules are simply not sufficient anymore to guarantee at least some minimum standards of sustainability. Cameroon is in fact a good case in point. Over the last two decades, the procedures to "manage" a CF have been officially simplified twice, with a participatory process that included NGOs, government officials, research organisations, and donors. These changes included both administrative and technical simplifications. Yet, all those changes do not seem to have brought about the intended results. In fact, results seem to indicate that political resistance to change remains the largest barrier to CFs' development. Simplifying procedures and reducing operational costs for $\mathrm{CF}$ should be complemented by increasing countervailing power for the communities to be able to oppose to elite capture. The difficulty for communities to hold out against the dominance of local elites in the processes of creating and managing FCs largely explains the choice of the individual owners to engage in informal chainsaw milling.

\section{Chainsaw milling: Managing trade-offs between legality and sustainability}

Given its current size, informal chainsaw milling must be given special attention in the ongoing reform of forest policy in Cameroon. Several reasons are often advanced by the administration to justify greater formalization of this sector: improving tax revenues, securing business, contributing to the development of rural territories, or a rational use of timber resources. However, as shown from our analysis of community forestry, the formalization of an activity does not always go hand in hand with maintaining or increasing its economic, social and environmental performance.

The formalisation of chainsaw milling would only be possible if the current level of employment and income, especially in rural areas, is maintained. This could be done by encouraging the operators to comply with technical, commercial and tax regulations that will increase the overall costs of production and, on the other hand, by convincing some administrative staff to give up corrupt practices that remain widespread. There is a high risk of coercion or taxation of chainsaw operators without the concurrent adoption of tough measures to improve governance. An unbalanced approach would simply urge individual operators to develop new ways to continue their informal activity.

Attracting small-scale operators toward legality requires a combination of technical and regulatory measures with an overall improvement of the business context for small and medium enterprises (SME).

Among the sub-sector measures, the simplification of regulatory procedures and their adaptation to the means of chainsaw millers would facilitate access to the law, for example by decentralizing procedure for granting permits. In parallel, the technical and commercial capacities of individual operators can be strengthened through training. However, these specific sub-sector approaches will remain inefficient without a gradual improvement in the business environment for SMEs (Macqueen 2014). Access to credit for individual and small businesses should be promoted. In rural areas, it is also necessary for the SMEs to develop a better understanding of urban markets, through an updated, regular and reliable communication. Finally, law enforcement by the administration must be improved, probably by combining financial incentives to implement regulations and effective sanctions against dishonest officials.

All these options will not, however, guarantee sustainability. It is not required from chainsaw loggers, and the current legal framework is not built for that. So, the government, and final buyers, should also be clear about the limitations that one or another harvesting model has. In this sense, there are no trade-offs between legality and sustainability in the chainsaw milling sector. Sustainability is not an objective and until the forest policy changes, one should not expect sustainable rules to be applied to the sub-sector.

One of the challenges for the government of Cameroon remains how to streamline the two models, with possible entry points for individual, local chainsaw millers into the $\mathrm{CF}$ model, so that the two models could become an integrated one, serving the domestic and regional market at least in a financially sustainable way, i.e. a way that could be profitable over the long-term, instead of depleting the resource to such an extent that recovery of the resource will be impossible.

\section{CONCLUSION}

In Cameroon, like in the other forest countries of Central Africa, STM has long been identified with logging concessions that, together with protected areas, were meant to ensure the maintenance of the forest cover on $30 \%$ of the country's area. Yet an important part of the national production of timber comes today from the exploitation of NPFE, through either semi-industrial permits or formal/informal artisanal logging. National and international policies - like the EU action plan on Forest Law Enforcement, Governance and Trade - are still struggling to recognize the importance of these types of timber exploitation which can be legal, even if they are not sustainable from an environmental point of view. In a general context where pressure on the NPFE is likely to accelerate in the coming years - as scheduled in Cameroon's Growth and Employment Strategy Paper - forest policy 
reforms must not only maintain the permanent forest estate but also limit forest degradation in the rural area. In this prospect, and due to its current and future extent, artisanal chainsaw logging needs to be supported to become legal, more efficient and environmentally sustainable. Two complementary approaches can be considered. First, in the medium term, a set of incentives should be designed and implemented to enforce the regulation on chainsaw milling. This approach requires for instance to make artisanal logging permits accessible to rural micro-entrepreneurs. On the other hand, it would be useful to link the application of the artisanal logging permits to an obligation of reforestation by the customary owners who sell "their" trees. However, the current institutional context is not supportive of local projects in afforestation (Foundjem-Tita et al. 2013) or in sustainable management of timber resources. In addition to technical and financial constraints, state ownership of land is the main difficulty to convince rural people to invest in forestry projects. Recognizing customary forms of-individual and collective-land tenure in the NPFE is probably a necessary step to secure investments in plantations and sustainable management of trees by farmers. This is also probably the best way to reduce the rate of net deforestation in the rural area and to counter longer-term threats to the permanent forest estate.

\section{ACKNOWLEDGEMENTS}

This research was conducted for the study "Etude de l'importance économique et sociale du secteur forestier et faunique du Cameroun" with the financial support of the Cameroon Forest and Environment Sector Programme. The authors thank Peter Biggins, Didier Devers and two anonymous referees for their comments and inputs on a preliminary version of this article.

\section{REFERENCES}

ABERNETHY, K.A., COAD, L., TAYLOR, G., LEE, M.E. and MAISELS, F. 2013. Extent and ecological consequences of hunting in Central African rainforests in the twenty-first century. Philosophical Transactions of the Royal Society B 368: 20120303.

AKOA AKOA, R.J. 2007. Economic analysis of community forest projects in Cameroon. Georg-August University of Goettingen, Faculty of Forest Science and Wood Ecology, M.Sc. thesis, Goettingen, Germany. 85 pp.

ASSEMBE MVONDO, S. 2009. Sustainable forest management practice in Central African States and customary law. International Journal of Sustainable Development \& World Ecology 16(4): 217-227.

ASSEMBE MVONDO, S., EBA'A ATYI, R., LESCUYER, G. and WARDELL, A. 2011. Sustainable forest management based on State practice in Central Africa countries. Nature \& Faune 26(1): 45-48.

AWONO, A., SOMORIN, O.A., EBA'A ATYI, R. and LEVANG, P. 2013. Tenure and participation in local
REDD+ projects: Insights from southern Cameroon. Environmental Science and Policy 35: 76-86.

BAYOL, N., ANQUETIL, F., BILE, C., BOLLEN, A., BOUSQUET, M., CASTADOT, B., CERUTTI, P.O., KONGAPE, J.A., LEBLANC, M., LESCUYER, G., MEUNIER, Q., MELET, E., PÉNELON, A., ROBIGLIO, V., TSANGA, R. and VAUTRIN, C. 2014. Filière bois d'œuvre et gestion des forêts naturelles. Les bois tropicaux et les forêts d'Afrique Centrale face aux évolutions des marchés. In: DE WASSEIGE, C., FLYNN, J., LOUPPE, D., HIOL HIOL, F. and MAYAUX, P. (ed.) Les forêts du bassin du Congo - État des Forêts 2013. Office des publications de l'Union Européenne, Weyrich. Belgique: 47-66.

BEAUCHAMP, E. and INGRAM, V. 2011. Impacts of community forests on livelihoods in Cameroon: Lessons from two case studies. International Forestry Review 13(3): $1-13$.

BIGOMBE LOGO, P. (ed.) 2004. Le retournement de l'Etat forestier. L'endroit et l'envers des processus de gestion forestière au Cameroun. Presses de l'UCAC, Yaoundé, Cameroun. 350 pp.

BRENT, R.J. 2006. Applied Cost-Benefit Analysis. 2nd edition, Edward Elgar, Cheltenham, UK. 473 pp.

BRUGGEMAN, D., MEYFROIDT, P. and LAMBIN, E.F. 2015. Production forests as a conservation tool: Effectiveness of Cameroon's land use zoning policy. Land Use Policy 42: 151-164.

CASTADOT, B. 2007. Analyse des filières formelle et informelle de sciages issus des forêts communautaires dans la province de l'est au Cameroun. Université des Sciences Agronomiques de Gembloux, M.Sc. dissertation, Gembloux, Belgique. 107 pp.

CERNEA, M. 1986. Putting people first: Sociological variables in rural development. World Bank Technical Paper 80, Washington D.C., USA. 602 pp.

CERUTTI, P.O. and TACCONI, L. 2008. Forests, illegality, and livelihoods: The case of Cameroon. Society and Natural Resources 21 (9): 845-853.

CERUTTI, P.O. and LESCUYER, G. 2011. The domestic market for small-scale chainsaw milling in Cameroon: present situations, opportunities and challenges. CIFOR Occasional Paper 61, Bogor, Indonesia. 56 pp.

CERUTTI, P.O., TACCONI, L., LESCUYER, G. and NASI, R. 2013. Cameroon's hidden harvest: Commercial chainsaw logging, corruption and livelihoods. Society and Natural Resources 26(5): 539-553.

COUNSELL, S., LONG, C. and WILSON, S. (ed.) 2007. Concessions to poverty. The environmental, social and economic impacts of industrial logging concessions in Africa's rainforests. Rainforest Foundation UK and Forests Monitor, London, England. 144 pp.

CUNY, P. 2011. Etat des lieux de la foresterie communautaire et communale au Cameroun. Tropenbos International, Wageningen, the Netherlands. 67 pp.

CUNY, P., ABE'ELE, P., NGUENANG, G.M., EBOULE SINGA, N.A., EYENE ESSOMBA, A. and DJEUKAM, R. 2004. Etat des lieux de la foresterie communautaire 
au Cameroun. MINEF and DFID, Yaoundé, Cameroon. $149 \mathrm{pp}$.

D'SILVA, E. and APPANAH, S. 1993. Forestry Management for Sustainable Development. World Bank, EDI Policy Seminar Report n³2, Washington D.C., USA. 134 pp.

DESCLÉE, B., MAYAUX, P., HANSEN, M., LOLA AMANI, P., SANNIER, C., MERTENS, B., HAUSLER, T., NGAMABOU SIWE, R., POILVE, H., GOND, V., RAHM, M., HAARPAINTNER, J. and KIBAMBE LUBAMBA, J.P. 2014. Evolution du couvert forestier du niveau national au régional et moteurs de changement. In: DE WASSEIGE, C., FLYNN, J., LOUPPE, D., HIOL HIOL, F. and MAYAUX, P. (ed.) Les forêts du bassin $d u$ Congo - État des Forêts 2013. Office des publications de l'Union Européenne, Weyrich. Belgique: 21-46.

DIETZ, S and NEUMAYER, E. 2007. Weak and strong sustainability in the SEEA: Concepts and measurement. Ecological Economics 61: 617-626.

EISEN, J., COUNSELL, S. and THORNBERRY, F. 2014. Rethinking community based forest management in the Congo Basin. Rainforest Foundation report, «Under the Canopy» series, London, England. 59 pp.

EKOKO, F. 2000. Balancing politics, economics and conservation: The case of the Cameroon forestry law reform. Development and Change 31(1): 131-154.

ETOUNGOU, P. 2003. Decentralization viewed from inside: The implementation of community forests in East Cameroon. World Resources Institute, Environmental Governance in Africa Working Paper $\mathrm{n}^{\circ} 12$, Washington D.C., USA. 25 pp.

EZZINE DE BLAS, D., RUIZ PÉREZ, M., SAYER, J.A., LESCUYER, G., NASI, R. and KARSENTY, A. 2009. External influences on and conditions for community logging management in Cameroon. World Development 37(2): 445-456.

EZZINE DE BLAS, D., RUIZ-PEREZ, M. and VERMEULEN, C. 2011. Management conflicts in Cameroonian community forests. Ecology \& Society 16(1): 8. URL: http://www.ecologyandsociety.org/vol16/iss1/art8/

FOUNDJEM TITA, D., TCHOUNDJEU, Z., SPEELMAN, S., D'HAESE, M., DEGRANDE, A., ASAAH, E., VAN HUYLENBROECK, G., VAN DAMME, P. and NDOYE, O. 2013. Policy and legal frameworks governing trees: Incentives or disincentives for smallholder tree planting decision in Cameroon? Small-scale Forestry 12: 489-505.

GLOBAL FOREST WATCH, MINFOF 2007. Interactive forestry atlas of Cameroon - Version 2.0 - An overview. World Resources Institute (WRI) and Ministry of Forests and Wildlife, Washington, D.C., USA and Yaoundé, Cameroon. 60 pp.

GOODLAND, R.J.A., ASIBEY, E.O.A., POST, J.C. and DYSON, M.B. 1991. Tropical moist forest management: The urgency of transition to sustainability. In: COSTANZA, R. (ed.) Ecological economics. The science and management of sustainability. Columbia University Press, New York, USA: 486-515.
INGRAM, V., NDOYE, O., MIDOKO IPONGA, D., CHUPEZI TIEGUHONG, J. and NASI, R. 2012. Les produits forestiers non ligneux: contribution aux économies nationales et stratégies pour une gestion durable. In: DE WASSEIGE, C., DE MARCKEN, P., BAYOL, N., HIOL HIOL, F., MAYAUX, P., DESCLÉE, B., NASI, R., BILLAND, A., DEFOURNY, P. and EBA'A ATYI, R. (ed.) Les forêts du bassin du Congo - Etat des Forêts 2010. Office des publications de l'Union Européenne, Luxembourg: 137-154.

JULVE, C., VANDENHAUTE, M., VERMEULEN, C., CASTADOT, B., EKODECK, H. and DELVINGT, W. 2007. Séduisante théorie, douloureuse pratique: la foresterie communautaire camerounaise en butte à sa propre législation. Parc et Réserves 62(2): 18-24.

JULVE, C., TABI ECKEBIL, P.P., NZOYEM SAHA, N., TCHANTCHOUANG, J.C., KERKHOFS, B., BEAUQUIN, A., MBARGA MBARGA, J.P., VERMEULEN, C., CERUTTI, P.O. and LESCUYER, G. 2013. Forêts communautaires camerounaises et FLEGT: quel prix pour la légalité? Bois et Forêt des Tropiques 317: 71-80.

KARSENTY, A., LESCUYER, G. and NASI, R. 2004. Est-il possible de déterminer des critères et indicateurs de gestion durable des forêts tropicales ? Revue Forestière Française LVI(5): 457-471.

KARSENTY, A, LESCUYER, G., EZZINE DE BLAS, D., SEMBRES, T. and VERMEULEN, C. 2010. Community forests in Central Africa: present hurdles and prospective evolutions. Article presented at the conference "Taking stock of smallholder and community forestry: where do we go from here?", March $24^{\text {th }}-26^{\text {th }}$, Montpellier, France. $11 \mathrm{pp}$.

KARSENTY, A. and GOURLET-FLEURY, S. 2006. Assessing Sustainability of Logging Practices in the Congo Basin's Managed Forests: the Issue of Commercial Species Recovery. Ecology and Society 11(1): 26. URL: http://www.ecologyandsociety.org/vol11/iss1/art26/

LEROY, M., DERROIRE, G., VENDÉ, J. and LEMÉNAGER, T. 2013. La gestion durable des forêts tropicales. De l'analyse critique du concept à l'évaluation environnementale des dispositifs de gestion. Agence Française pour le Développement, collection «A Savoir» $\mathrm{n}^{\circ} 18$, Paris, France. 237 pp.

LESCUYER, G. 2013. Sustainable forest management at the local scale: A comparative analysis of community and domestic forests in Cameroon. Small-scale Forestry 12(1): 51-66.

LESCUYER, G., YEMBE-YEMBE, R.I. and CERUTTI, P.O. 2011. The domestic market for small-scale chainsaw milling in the Republic of Congo: Present situation, opportunities and challenges. CIFOR Occasional Paper 74, Bogor, Indonesia. 44 pp.

LESCUYER, G., ASSEMBE MVONDO, S. ESSOUNGOU, J., TOISON, V., TRÉBUCHON, J.F. and FAUVET, N. 2012. Logging concessions and local livelihoods in Cameroon: from indifference to alliance? Ecology and Society 17(1): 7. URL: http://www.ecologyandsociety. org/vol17/iss1/art7/ 
LESCUYER, G., CERUTTI, P.O. and ROBIGLIO, V. 2013. Artisanal chainsaw milling to support decentralized management of timber in Central Africa? An analysis through the theory of access. Forest Policy and Economics 32: 68-77.

LESCUYER, G., CERUTTI, P.O., TSHIMPANGA, P.C., BILOKO, F., ADEBU ABDALA, B., TSANGA, R., YEMBE YEMBE, R.I. and ESSIANE MENDOULA, E. 2014. The domestic market for small-scale chainsaw milling in the Democratic Republic of Congo: Present situation, opportunities and challenges. CIFOR Occasional Paper 112, Bogor, Indonesia. $62 \mathrm{pp}$.

LESCUYER, G., TSANGA, R., ESSIANE MENDOULA, E. and NDUME ENGONE, H.C. 2015. Stock taking of smallscale forest enterprises involved in commercialization of timber in Central Africa. CIFOR technical report for FAO, Rome, Italy. 43 pp.

LESCUYER, G. and TAL, M. 2016. Intra-African trade of timber: the Cameroon-Chad case in 2015. A CIFOR report for ITTO, Bogor, Indonesia. $22 \mathrm{pp}$.

LUCKERT, M.K., and WILLIAMSON, T. 2005. Should sustained yield be part of sustainable forest management? Canadian Journal of Forest Research 35: 356-364.

MACQUEEN, D. (ed.) 2014. Prioritising support for locally controlled forest enterprises. IIED, Forest Connect, Forest and Farm Facility, London, England. 232 pp.

MEUNIER, Q., BOLDRINI, S., MOUMBOGOU, C., MORIN, A., IBONGA, S. and VERMEULEN C. 2014. Place de l'agriculture itinérante familiale dans la foresterie communautaire au Gabon. Bois et Forêts des Tropiques 319: 65-69.

MINANG, P., BRESSERS, H.T., SKUTSCH, M.M. and MCCALL, M.K. 2007. National forest policy as a platform for biosphere carbon management: The case of community forestry in Cameroon? Environmental Science and Policy 10: 204-218.

NASI, R., BILLAND, A. and VAN VLIET, N. 2012. Managing for timber and biodiversity in the Congo Basin. Forest Ecology and Management 268: 103-111.

NDUME ENGONE, H.C. 2010. Analyse financière des impacts de l'exploitation du bois d'ouvre dans les économies villageoises du Sud-Cameroun. ENGREF, M. Sc. dissertation, Montpellier, France. 74 pp.

NZOYEM, N., VABI, M., KOUOKAM, R. and AZANGA, C. 2010. Forêts communautaires contre la pauvreté, la déforestation et la dégradation des forêts: en faire une réalité au Cameroun. Article presented at the conference "Taking stock of smallholder and community forestry: where do we go from here?", March $24^{\text {th }}-26^{\text {th }}$, Montpellier, France. $14 \mathrm{pp}$.

OYONO, R.P. 2004. Institutional deficit, representation, and decentralized forest management in Cameroon. Elements of natural resource sociology for social theory and public policy. WRI \& CIFOR, Environmental Governance in Africa Working Papers 15, Washington D.C., USA. 65 pp. OYONO, P.R. 2005. Profiling local-level outcomes of environmental decentralizations: The case of Cameroon's forests in the Congo Basin. Journal of Environment and Development 14(2): 1-21.

OYONO, P.R., RIBOT, J.C. and LARSON, A.M. 2006. Green and black gold in rural Cameroon: Natural resources for local governance, justice and sustainability. WRI Environmental Governance in Africa, Working paper $\mathrm{n}^{\circ} 22$, Washington D.C., USA. 92 pp.

PANAYOTOU, T. and ASHTON, P. 1992. Not by timber alone. Economics and ecology for sustaining tropical forests. Island Press, Covelo, CA, USA. 280 pp.

PEARCE, D., PUTZ, F. and VANCLAY, J.K. 1999. A Sustainable Forest Future. University College London \& University of East Anglia, CSERGE Working Paper GEC 99-15, London, England. 64 pp.

PLOUVIER, D., EBA'A ATYI, R., FOUDA, T., OYONO, R. and DJEUKAM, R. 2002. Etude du sous-secteur du sciage artisanal au Cameroun. MINEF, Yaoundé, Cameroon. $70 \mathrm{pp}$.

POISSONNET, M., PARMANTIER, A., WYNGAARDE, B., BIFANE ELLE, E., DEMENOIS, J. and LESCUYER, G. 2006. Espoirs et difficultés du transfert de la gestion forestière à deux communautés de Guyane et du Cameroun. Bois \& Forêts des Tropiques 289: 5-16.

POORE, D., BURGESS, P., PALMER, J., RIETBERGEN, S. and SYNNOTT, T. 1989. No timber without trees: Sustainability in the tropical forest. Earthscan, London, UK. 252 pp.

REM 2007. Mission conjointe BNC-Observateur indépendant: Forêts communautaires du Haut-Nyong, Lomié. Report of the Independent Observer $n^{\circ} 080 / O I / R E M$, Yaoundé, Cameroon. 34 pp.

ROBIGLIO, V., LESCUYER, G. and CERUTTI, P.O. 2013. From farmers to loggers: the role of shifting cultivation landscapes in timber production in Cameroon. Smallscale Forestry 12(1): 67-85.

SAMYN, J.M., GASANA, J., POUSE, E. and POUSSE, F. 2011. Secteur forestier dans les pays du Bassin du Congo: 20 ans d'intervention de l'AFD. Agence Française de Développement, Paris, France. 187 pp.

SMOUTS, M.C. 2001. Forêts tropicales, jungle internationale. Les revers d'une écopolitique mondiale. Presses de Sciences-Po, Paris, France. 349 pp.

TOMAN, M. and ASHTON, P.M.S. 1996. Sustainable Forest Ecosystems and Management: A Review Article. Forest Science 42(3): 366-377.

TOPA, G., KARSENTY, A., MEGEVAND, C. and DEBROUX, L. 2009. Forêts tropicales humides $d u$ Cameroun. Une décennie de réformes. Banque Mondiale, Washington D.C., USA. 197 pp.

VERMEULEN, C., VANDENHAUTE, M., DETHIER, M., ECKODEK, H., NGUENANG, G.M. and DELVINGT, W. 2006. De Kompia à Djolempoum: sur les sentiers tortueux de l'aménagement et de l'exploitation des forêts communautaires au Cameroun. VertigO 7(1).

WIERSUM, K.F. 1999. Social forestry: Changing perspectives in forestry science or practice? Wageningen Agricultural University, Ph.D. thesis, Wageningen, The Netherlands. 211 pp. 